\title{
ClassifiCATION OF LANDUSE USING TIME SERIES ANALYSIS OF KOTA TINGGI DISTRICT, JOHOR BAHRU, MALAYSIA.
}

\section{Alhaji Mustapha isa*}

Department of Geoinformatics, Faculty of Built Environment and Surveying Universiti Teknologi Malaysia, 81310 UTM Skudai, Johor Bahru, Malaysia.

Institute for Geospatial Science and Technology (INSTeG)

Universiti Teknologi Malaysia, 81310 UTM Skudai, and Johor Bahru,

Malaysia.

Mai Idris Alooma Polytechnic,

P.M.B. 1020, Geidam, Yobe State,

Nigeria.

\section{Mazlan Hashim}

Department of Geoinformatics, Faculty of Built Environment and Surveying Universiti Teknologi Malaysia, 81310 UTM Skudai, Johor Bahru, Malaysia.

Institute for Geospatial Science and Technology (INSTeG)

Universiti Teknologi Malaysia, 81310 UTM Skudai Johor Bahru, Malaysia.

\section{Danboyi joseph Amusuk}

Department of Geoinformatics, Faculty of Built Environment and Surveying Universiti Teknologi Malaysia, 81310 UTM Skudai, Johor Bahru,

Malaysia.

Institute for Geospatial Science and Technology (INSTeG)

Universiti Teknologi Malaysia, 81310 UTM Skudai, and Johor Bahru,

Malaysia.

Waziri Umaru Federal Polyechnic,

P.M.B. 1034, Birnin Kebbi, Kebbi State,

Nigeria.

*Corrosponding author's Email: almustapha459@gmail.com

Peer-review under responsibility of $3^{\text {rd }}$ Asia International Multidisciplanry Conference 2019 editorial board (http://www.utm.my/asia/our-team/) (C) 2019 Published by Readers Insight Publisher, lat 306 Savoy Residencia, Block 3 F11/1,44000 Islamabad. Pakistan, info@ readersinsight.net This is an open access article under the CC BY-NC-ND license (http://creativecommons.org/licenses/by-nc-nd/4.0/). 


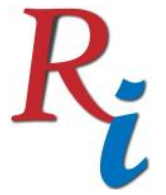

Asia Proceedings of Social Sciences

(APSS)

www.readersinsight.net/APSS

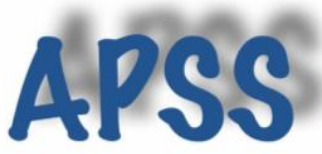

\section{Rese a r ch H i g h I igh t s}

Deforestation and climate change have become global environmental issues. The detection of forest changes in association with climate change can be successfully carried out by the use of multi-temporal remote sensing and modelling. This study undertook analysis of the past and present condition of the forest from the pattern changes of the Kota tinggi district johor state Malaysia, using landsat images of three different periods. These are thematic mapper (TM) data of 1998; enhanced thematic mapper (ETM+) image of 2008 and the operation land imager (OLI) of 2018 were collectively used. The images were geometrically and atmospherically preprocessed then classified, using maximum likelihood (M/C) algorithm to produce thematic land use/cover maps of the district. The accuracy of the classification was assessed through ground truthing and confusion matrices which revealed an accuracy of above 90\% and kappa coefficient at 0.9 respectively.

\section{Graphic a I A bst r a c t}

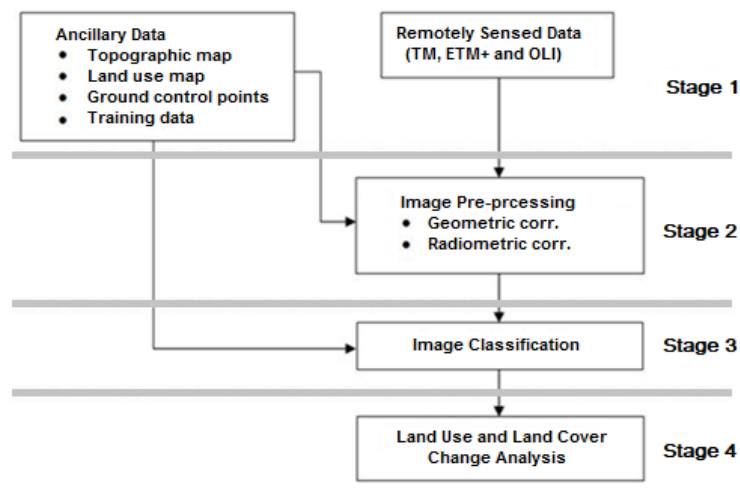

Fig. 1: Methodology Framework

\section{Research Objectives}

This study aims at investigating the changes that has occurred in forest as a result of climate change using multi-temporal RS techniques. The aim of this study was achieved from the following Objectives. (1).To detect the long term forest cover changes using Landsat multispectral satellite data Image in classification. (2). To obtain reliable information on the landuse and landcover. This study will broaden the knowledge on the strength of Satellite RS by assessing the present and predicting the future impact of climate change on forest land-use changes. The proposed approach will serve as a powerful tool for predicting forest land-use changes from spatial and temporal perspectives. This will support decision-making process for ecosystem conservation and management. In addition, the proposed approach requires satellite, precipitation, and population data as major input, and all these are obtainable from open sources, which makes it preferable and cost effective in terms of implementation

\section{Methodology}

The land use/cover categories in the study area were grouped into six major classes; agricultural lands, bare surface, built-up area, forest, oil palm and water body. Training samples were created and in ArcGIS software using bands 542 for Landsat TM of 1998, bands 542 for Landsat ETM+ of 2008, and bands 753 as equivalent for Landsat OLI of 2018. There are 


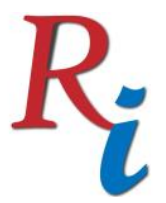

\section{Asia Proceedings of Social Sciences \\ (APSS) \\ www.readersinsight.net/APSS}

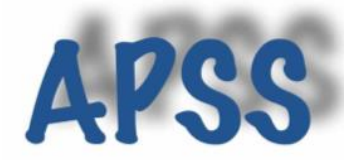

researchers that have applied this methodology (Mallupattu and Sreenivasula Reddy, 2013). supervised classification approach was employed to classify the images using maximum likelihood classifier, known to be widely used as a classification algorithm (Richards and Jia, 1999, Otukei and Blaschke, 2010). Table 1 presents the classified images with their overall accuracies and Kappa indexes.

\section{Results}

Moreover, the dominant change that occurred in the study area within the study period is in the built-up area which occupied $4114.98 \mathrm{Ha}$ in 1998, 12244.51Ha in 2008 and $26886.06 \mathrm{Ha}$ in 2018. Thus, between 1998 and 2018, the built-up area has increased by almost $22771.08 \mathrm{Ha}$ or nearly $553.37 \%$. Other categories where positive changes were observed are agricultural land, bare surface and oil palm which occupied: $26265.06 \mathrm{Ha}, 4459.05 \mathrm{Ha}$ and $70927.29 \mathrm{Ha}$ in 1998; $28828.67 \mathrm{Ha}, 6976.32 \mathrm{Ha}$ and $116492.22 \mathrm{Ha}$ in 2008 ; and $33826.32 \mathrm{Ha}, 11168.28 \mathrm{Ha}$ and 145056.60Ha in 2018. Thus, between 1998 and 2018, the agriculture, bare surface and oil palm have declined by $7561.26 \mathrm{Ha}, 6709.23 \mathrm{Ha}$ and $74129.31 \mathrm{Ha}$, or nearly $28.79 \%, 150.46 \%$ and $104.51 \%$, respectively. Negative changes were observed in forest and water body within the study period. They occupied $228639.33 \mathrm{Ha}$ and $13599.90 \mathrm{Ha}$ in $1998,171252.36 \mathrm{Ha}$ and 12211.54Ha in 2008, and 120259.17Ha and 10809.18Ha in 2018, respectively. Thus, between 1998 and 2018, the forest and water body have declined by $108380.16 \mathrm{Ha}$ and $2790.72 \mathrm{Ha}$, or nearly $47.40 \%$ and $20.52 \%$, respectively. The decline in forest and increase in bare surface, agricultural land and oil palm are as a result of falling down of trees for wood, and change over from forest to farmland and oil palm plantation..

\section{Findings}

The study has been conducted using multi-temporal Landsat satellite images of three different years; Thematic Mapper (TM) of 1998, Enhanced Thematic Mapper (ETM+) of 2008 and Operational Land Imager (OLI) of 2018 to examine the LU/LC changes in Kota Tinggi District of Johor State, Malaysia over a period of two decades (1998-2018). The results of the analysis revealed that the following changes have taken place in agricultural land $(+28.79 \%)$, bare surface $(+150.46 \%)$, built-up area $(+553.37 \%)$, forest $(-47.40 \%)$, oil palm $(+104.51 \%)$ and water body $(-20.52 \%)$ within the study period. This shows a rapid decrease in the natural forest, which may be partly attributed to anthropogenic activities and partly to climate change impact. The study has proved the potencies of geospatial technique for examining LU/LC changes and the result will serve as input into land change model for predicting future forest changes in the area.

\section{Acknowledgement}

I appreciate Mai Idris Alooma Polytechnic, P. M. B 1020 Geidam and TETFUND who supported me with Intervention to Malaysia, to undertake my MSc in Remote Sensing.

\section{References}

MALLUPATTU, P. K. \& SREENIVASULA REDDY, J. R. 2013. Analysis of land use/land cover changes using remote sensing data and GIS at an Urban Area, Tirupati, India. The Scientific World Journal, 2013.

OTUKEI, J. R. \& BLASCHKE, T. 2010. Land cover change assessment using decision trees, support vector machines and maximum likelihood classification algorithms. International Journal of Applied Earth Observation and Geoinformation, 12, S27-S31.

RICHARDS, J. A. \& JIA, X. 1999. Remote sensing digital image analysis, Berlin, Springer. 